\title{
ETIOLOGY AND PATHOGENESIS OF HYPOGONADISM IN MEN IN MODERN CONDITIONS
}

\section{Etiology and pathogenesis of hypogonadism in men in modern conditions}

R. B. Druziuk, O. V. Denefil

I. Horbachevsky Ternopil National Medical University

e-mail denefil@tdmu.edu.ua

Summary. Acute and chronic stress, COVID-19 and male hypogonadism are interrelated.

The aim of the study - to analyze the literature on the interactions of stress, COVID-19 and male hypogonadism, to trace the main links in the pathogenesis.

Materials and Methods. The study examined scientific publications over the past decade, which are available on the Internet, the key words were "COVID-19", "male hypogonadism", "acute stress", "chronic stress", "pathogenesis".

Results. In order to study in more detail the effect of stress in COVID-19 on male hypogonadism, the pathogenetic chains of three separate vicious circles are considered separately: "COVID-19 and stress", "COVID-19 and male hypogonadism", "stress and male hypogonadism". Attention is paid to pathogenetic mechanisms in the presence of all three factors: COVID-19, stress and male hypogonadism.

Conclusions. The link between the effects of stress, COVID-19 and male hypogonadism has been proven. The main pathogenetic links of these interdependent processes are described.

Key words: men; stress; COVID-19; hypogonadism.

\section{INTRODUCTION}

To date, in the course of repeated long-term observations and numerous scientific studies, there is a significant impact of stress on the pathophysiological mechanisms of many diseases. These include the influence of stressors on the development of male hypogonadism and, conversely, the conditionality of the development of chronic stress by sexual dysfunction and deterioration of sexual intercourse due to hypogonadism.

At the same time, as part of the latest research on the effects of coronavirus (COVID-19) on the human body, Chinese scientists have found that this vi-

\section{Етіологія та патогенез гіпогонадизму в чоловіків у сучасних умовах}

Р. Б. Друзюк, О. В. Денефіль

Тернопільський національний медичний університет імені І. Я. Горбачевського МОЗ України

Резюме. Гострий та хронічний стреси, COVID-19 та чоловічий гіпогонадизм взаємопов'язані між собою.

Мета дослідження - проаналізувати літературні джерела щодо взаємовпливів стресу, COVID-19 ma чоловічого гіпогонадизму, простежити основні ланки патогенезу.

Матеріали і методи. У дослідженні опрацьовано наукові публікації за останнє десятиліття, які доступні у мережі «Інтернет», ключовими словами були «COVID-19», «чоловічий гіпогонадизм», «гострий стрес», «хронічний стрес», «гострий стрес», «патогенез».

Результати. 3 метою детальнішого вивчення впливу стресу при COVID-19 на чоловічий гіпогонадизм, окремо розглянуто патогенетичні ланцюги трьох окремих хибних кіл: "COVID-19 та cmpec», "COVID-19 та чоловічий гіпогонадизм», «стрес та чоловічий гіпогонадизм». Звернено увагу на патогенетичні механізми за наявності усіх трьох фракторів: COVID-19, стрес та чоловічий гіпогонадизм.

Висновки. Доведено зваємозв'язок між впливами cmpecy, COVID-19 та чоловічого гіпогонадизму. Описано основні патогенетичні ланки цих взаємозумовлених процесів.

Ключові слова: чоловіки; стрес; COVID-19; гіпогонадизм.

rus has a detrimental effect on testicular function and male reproductive function. The researchers demonstrated a relationship between coronavirus infection and the development of testicular failure [1,2], and substantiated the corresponding determinism of a worse prognosis for COVID-19 in men and low testosterone levels [3].

In a pandemic, stress becomes a factor that affects people's lives in one way or another. For example, the situation of social isolation leads to long-term activation of the sympatho-adrenal system. In people who have lost a family member, recorded a particularly significant excretion of catecholamines 
and acute damage to various organs and systems. People affected by COVID-19 were treated in medical institutions, separated from their relatives, saw deaths around them, and therefore had an increased excretion of catecholamines (varying degrees of epinephrine and nor epinephrine). Of course, it complicates the course of diseases caused by the virus COVID-19.

Given the above, we can note the interconnected vicious circles that reinforce each other (Figure 1).

The aim of the study was to analyze the literature on the spread of male hypogonadism in acute and chronic stress and in epidemic of COVID-19, tracking the main links in the study of pathogenesis, drawing parallels with the interaction of these factors.

\section{MATERIALS AND METHODS}

The study examined scientific publications over the past decade, which are available on the Internet, the key words were "COVID-19", "male hypogonadism", "acute stress", "chronic stress", "pathogenesis".

\section{RESULTS}

Stress and male hypogonadism. Stress is usually a natural phenomenon that affects behavior, physiological processes and neuroendocrine, neurochemical, neural and immune responses. It is supposed that many somatic and mental disorders are the result of chronic stress. Stress-induced gonadal dysfunction is observed not only in humans but also in all higher animals. Stress-induced gonadal dysfunction includes disorders of the hypothalamic-pituitarygonadal axis and spermatogenesis. Various stressors induce changes in the secretion of neurotransmitters and hormones, such as corticotropin-releasing hormone, vasopressin, beta-endorphins, somatostatin, vasoactive intestinal polypeptide, prolactin, gonadotropin, thyroid-stimulating hormone, dopamine, serotonin, neuropeptide $\mathrm{Y}$, melatonin, adrenocorticotropic hormone (ACTH), glucocorticosteroids (GCS), catecholamines and androgens [4].

In this context, it seems appropriate to consider separately the effects of acute and chronic stress (both related to the action of COVID-19 virus) on the hormonal status, because, despite the common links in the pathogenesis, the latter are marked by significant differences in their hormonal changes.

Acute stress is accompanied by modification of testicular function mainly by cytokines and its fluctuations due to gonadotropin concentrations, while chronic stress is accompanied by hypogonadotropic hypogonadism and impaired spermatogenesis of varying severity, up to spermatogenesis. The action of COVID-19 virus has a double detrimental effect on testicular function - stress cytokines and proinflammatory cytokines associated with the COVID-19 virus.

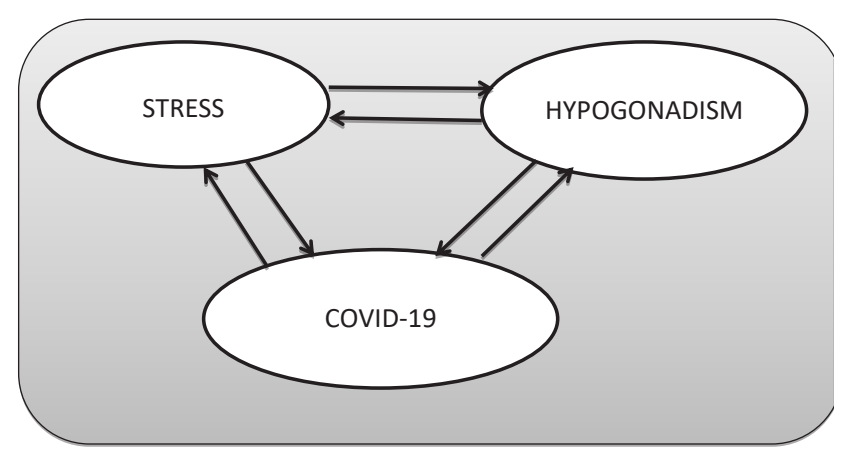

Figure 1

Physiological stress, which does not yet disrupt the compensation mechanisms, to some extent increases the production of somatotropic hormone. However, chronic stress causes increased somatostatin production and suppression of somatotropin. Somatotropin deficiency causes mild fatigue, loss of sexual desire, loss of erection and oligo- or azoospermia [5]. Somatostatin, on the other hand, causes suppression of serotonin production and, consequently, frequent depressive and anxiety states that do not promote adequate sexual behavior.

Melatonin has a significant anti-stress effect. The role and functions of melatonin are unique and include: 1) regulation of circadian and seasonal rhythms; 2) regulation of the psycho-emotional and cognitive spheres; 3) antioxidant, neuroprotective, geroprotective action; 4) immunomodulatory action; 5) oncoprotective action; $6)$ universal stress-protective effect. Melatonin realizes its effects in two ways: 1) through a system of specific melatonin receptors (MT1, MT2, MT3), which are different in function (excitatory and inhibitory), localization (membrane and nuclear) and are widely represented in the central nervous system and peripheral organs; 2) based on interaction with other nuclear receptors and subcellular structures due to free penetration through all tissue and histohematological barriers [6].

The effect of chronic stress, among other things, is marked by depletion of melatonin resources. This will manifest itself in insomnia at night and drowsiness during the day; disorders in the emotional sphere and cognitive activity; an even greater reduction in overall stress resistance. In addition, a decrease in the antioxidant, neuroprotective, immunomodulatory properties of melatonin will increase the detrimental effects of the COVID-19 virus.

At the present stage, the importance of melatonin for maintaining spermatogenesis and regulating reproductive function in men has been proven. Chronic melatonin deficiency, associated with sleep-wake disorders, naturally leads to an increase in sex hormone deficiency and insulin resistance due to progressive obesity and oxidative stress, including oxidative stress in sperm. That is, the lower the level of melatonin in the blood, the more pronounced is the oxidative stress of sperm, because sleep hormone is a powerful 
antioxidant and mitochondrial protector. According to many authors, melatonin plays the role of a kind of "testicular protector", protecting testicular tissue from ischemia, hypoxia, oxidative stress, including obesity, and, consequently, from irreversible loss of functioning germinogenic epithelium [7].

Dehydroepiandrosterone (or DHEA) is a hormone with androgenic activity. DHEA is responsible for the development of secondary sexual characteristics, maintenance of sexual function, and has an anabolic effect. $90 \%$ of the hormone is produced in the adrenal cortex, the other $10 \%$ is synthesized in men in the testicles and in the ovaries in women. Cholesterol is considered a precursor to DHEA, and other steroid hormones are considered successors. In men, DHEA is subject to conversion to stronger androgens - testosterone and androstenedione, in women - estrogen and progesterone. Hormone production continues under the control of ACTH. Chronic stress can lead to a decrease in DHEA, indicating the development of adrenal stress syndrome [8]. This, in turn, is accompanied by a decrease in the synthesis of testosterone and androstenediol.

Testosterone is the main sex steroid that provides reproductive function in the male body. On the other hand, as an anabolic hormone, it is involved in the regulation of plastic and reparative processes [9, 23]. In the central nervous system, testosterone and its metabolites work as neurosteroids, as they are involved in the formation of learning, memory, socio-behavioral motivation $[10,23]$. Testosterone helps maintain an adequate body response to stress. In animal experiments, testosterone has been shown to suppress the hypothalamic-pituitary-adrenocortical response to stress, while estrogen alleviates it $[11,23]$. Stress in animals has been shown to inhibit testosterone synthesis and spermatogenesis due to blockade of gonadotropin receptors and, consequently, the absence of luteinizing hormone (LH) and follicle-stimulating hormone, leading to the cessation of testosterone and gametogenesis. On the other hand, suppression of testosterone secretion in the case of chronic exposure to extreme external factors is possible regardless of the high content of $\mathrm{LH}$ due to reduced sensitivity of the testes to the activating action of tropical hormones $[13,23]$. The change in the function of the gonads in the presence of stress is largely due to the duration of exposure to the extreme factor, its nature, the initial state of the organism. These factors can directly affect both the central and peripheral links not only of the hypothalamic-pituitary-gonadal system (HPGS), but also of other systems of response regulation, as they form a certain pathogenetic mechanism of damage [14, 23]. The duration of stressors is a determining factor in testosterone synthesis. During animal experiments, due to the combination of stress with active exercise in the first time from the moment of exposure, an increase in the level of testosterone circulating in the blood is observed, but later, in the case of long-term stressor, its decrease is observed [15, 23]. The initial increase in testosterone release under stress is more related to the activation of HPGS, active gonadotropin secretion and, consequently, LH. Similar changes in testosterone concentration occurred in the case of experimental modulation of stress by raising the ambient temperature $[16,23]$. Later, the sympathoadrenal link (mechanisms of urgent adaptation) begins to take part in this process, the active substances of which have an inhibitory effect on testosterone secretion $[17,23]$. Activation of the adrenocortical link causes the blocking of receptors on Leydig cells that synthesize testosterone and are exposed to GCS [18, 23]. At the same time, ACTH, which has a stimulating effect on neurons that secrete gonadotropins, enhances the production of gonadotropins [19, 23]. Given this, there is a paradoxical effect: when level of $\mathrm{LH}$ in the blood is increasing, there is a further significant decrease in testosterone levels $[20,23]$. Similar reactions in HPGS are inherent in the person. It is known that long-term or short-term exercises lead to an increase in cortisol levels with unchanged $\mathrm{LH}$ with a simultaneous decrease in testosterone levels in men [21, 23]. During the simulation of stress with reduced physical activity (immobilization), the decrease in testosterone secretion unfolds in another pathogenetic way. The general decrease in physical activity is also inherent in long-term quarantine isolation. In this case, corticoliberin blocks luliberin cells, which, accordingly, causes inhibition of LH and testosterone synthesis. One of the possible mechanisms of testosterone reduction, not related to the secretion of gonadotropins, is considered to be a shift in metabolism towards catabolic processes over anabolic ones due to hypersecretion of cortisol [22, 23].

Acute and chronic stress are accompanied by a significant increased risk of developing diabetes. For example, men with prediabetes have lower levels of total testosterone and sex hormone-binding globulin in their blood [29]. It should be added that total testosterone and sex hormone-binding globulin are independent risk factors for metabolic syndrome [36].

Hypogonadism occurs more often in men with a combination of type 2 diabetes and coronary heart disease (40 \%) than in men with only type 2 diabetes (32\%) compared with the control group of healthy individuals (14\%) [34].

The metabolic syndrome deserves special consideration. Metabolic syndrome and male hypogonadism are mutually determined and interdependent [30]. Metabolic syndrome, first described by Reaven in 1988 as "syndrome X", or "insulin resistance syndrome", is a group of common disorders, such as: insulin resistance, impaired glucose tolerance, abdominal obesity, decreased levels of HDL-cholesterol, and hypertension [31, 32, 33]. The general cause of such violations remains unknown today. However, this condition is considered to be the result of a sedentary lifestyle, overeating, and as a conse- 
quence-obesity, which is common in the modern world. Metabolic syndrome is associated with endothelial dysfunction and atherosclerosis, leading to an increased risk of cardiovascular disease and type 2 diabetes [31, 32]. In the presence of metabolic syndrome, the levels of total and free testosterone in men were much lower than normal compared to women [35].

Stress and COVID-19. In addition to the above hormones, which directly and indirectly affect male hypogonadism and the body's protective reactions in particular, consider other hormones that obviously affect the body under stress and the study of which is especially relevant for existing immuno-inflammatory, immuno-cytokine, oxidative mechanisms of development pathological conditions caused by COVID-19 infection.

Prolactin - one of the oldest hormones of the pituitary gland, which main function is to stimulate lactation, is present in fairly large quantities in the male body. Receptors for prolactin are present in the cells of most tissues, which suggests that its role in the body is extremely multifaceted: prolactin is involved in almost all regulatory processes, having a synergistic or antagonistic effect on biologically active substances $[23,24]$. The known anti-stress role of prolactin is determined by the fact that it prevents the development of stress-induced catabolic reactions mediated by hypersecretion of GCS. Due to the extreme influence of various factors that contribute to the development of stress, there is a change in the content of prolactin in the blood (its dynamics largely depends on the duration and intensity of this effect) $[23,25]$. Modeling of stress is accompanied by a significant increase in the concentration of prolactin, which offsets the catabolic effect of GCS. However, in the case of prolonged exposure to stressors GCS is intensively produced due to the activation of the hypothalamic-pituitary-adrenal system, inhibits the secretion of prolactin until its complete blockade $[23,26]$. In this way, one of the most important compensatory links is deactivated with appropriate preconditions for the development of stress.

Under the influence of stress, vasopressin acts inconsistently in the body. Thus, due to V1-receptors, which are located in vascular myocytes, liver and brain, under such powerful factors as stress, shock and a significant increase in blood pressure (which is also characteristic of stress), vasopressin plays a significant role, despite low affinity for such receptors. On the other hand, under the influence of adrenaline there is a decrease in vasopressin production. However, the effect of vasopressin on the kidneys and urination due to $V_{2}$ receptors, which are located on the cell membranes of the distal tubules and collecting tubules of the kidneys, remains significant due to the possibility of increased blood pressure due to antidiuretic and vasospastic effects [27]. In addition to vasoconstrictive effects on the esophageal veins and glomerular capillaries, vasopressin also actively narrows the vessels of the coronary arteries, which may contribute to or exacerbate myocardial ischemia and hypoxia by supplementing the adrenomimetic action of catecholamine stress and systemic hypertension.

During stress, due to the indirect stimulating effect of corticotropin-releasing hormone and $\mathrm{ACTH}$, there is an increase in the production of glucocorticoids. The effects of cortisol during stress are so significant that it is even called the "enemy of health number 1" [28]. Chronic stress or constant anxiety does not provide a physical way out for cortisol and leads to the end of the "fight or flight" mechanism. This leads to unpleasant consequences. Ironically, human biology, which was supposed to ensure the survival of humans as hunters and gatherers, destroys the body and nous in a digital age with a sedentary lifestyle [28]. This impact is even more pronounced in the context of social isolation during the COVID-19 pandemic. The cumulative effect of an isolated and tense society causes an increase in cortisol levels in all directions for people of all ages. This is creating a crisis in the health care system around the world.

Specify that cortisol contributes to anxiety, depression, headaches; weakening of the immune system; diseases of the cardiovascular system, hypertension, hyperglycemia and the development of diabetes mellitus; digestive problems.

There are ambiguous questions about the use and action of catecholamines in COVID-19 lesions. The use of adrenaline during resuscitation is the main means of eliminating cardiac arrest, but the safety and efficacy of this agent remain controversial. Vasopressin has been proposed as an alternative to adrenaline to eliminate cardiac arrest on the grounds that its levels were markedly higher in healthy patients than in those who had already died. Compared with adrenaline, vasopressin has a number of advantages, in particular, increases peripheral arterial resistance without direct stimulation of the myocardium; more resistant to acidosis and has a longer half-life; does not ignite - most importantly - a cytokine storm. Although vasopressin was not shown to be superior to epinephrine in total cardiac arrest in any clinical trial, the use of vasopressin to relieve cardiac arrest in patients with COVID-19 should still be fully evaluated for cytokines. Given the need to balance the risks and benefits of treatment in clinical decisions, it seems timely to rethink the effects of epinephrine on patients with COVID-19 with a cytokine storm. The use of other agents (eg, vasopressin) should be compared with epinephrine, and their potential as an alternative strategy should be fully evaluated [37, 38, 39, 40].

Interesting was the fact that epinephrine enhances the cytokine storm during immunotherapy [41].

A significant change in the general hormonal background due to stress and immuno-cytokine, oxidative links of pathogenesis in the presence of 
COVID-19 forces to pay special attention to the damage not only to the lung tissue but also to the myocardium.

To date, the medical community has accumulated little data on the specifics of myocardial damage in the presence of COVID-19 [42]. However, scientists are unanimous in their view of the direct damaging effects of the SARS virus on the myocardium in general [43]. Acute heart disease, characterized by a significant increase in cardiac troponin levels, is the most common (approximately 8-12\% of all patients) among cardiac abnormalities caused by COVID-19. Direct damage to the myocardium due to viral damage to cardiomyocytes and the effect of systemic inflammation should be considered, perhaps, the most common mechanisms responsible for heart damage. Information on other manifestations of cardiovascular diseases due to COVID-19 remains very limited today. Nevertheless, it is known that the presence of cardiovascular disease in patients before COVID-19 and/or the development of acute heart damage in them is associated with a much worse prognosis for them [44].

Hypogonadism and COVID-19. According to scientists, low testosterone levels are the reason for a worse prognosis for COVID-19 in men (much worse than for estrogen) [45]. A detailed study found that hypogonadism, which leads to testosterone deficiency, can exacerbate a cytokine storm [46].

The researchers tracked some new pathophysi- ological mechanisms of COVID-19's effects on the male reproductive system. Thus, SAR-CoV2 can act through several mechanisms of male reproductive dysfunction. The point is that the virus activates oxidative stress (OS), which is a common pathological mechanism of disruption of certain physiological functions due to oxidative tissue damage. OS-mediated mechanisms of male infertility are widely documented, as OS affects sperm quality and disrupts sperm function and morphology [47]. Intracellular oxidative damage to sperm occurs due to lipid peroxidation of the sperm membrane, damage to sperm DNA, and induction of apoptotic pathways in sperm [47,48, 49]. During SARS-CoV infections, overproduction of reactive oxygen species can trigger, for the most part, nuclear factor-enhancing kappa light chain pathways of activated B-cell (NF-KB) -toll-like receptors (mainly TLR-4) [50]. This further stimulates the release of cyo tokines, causing increased inflammatory responses [50]. As mentioned above, the virus can potentially cause orchitis, and later - the induction of OS. Even more, SARS-CoV-2 infection activates psychological stress, which is the main cause of systemic OS [51].

\section{CONCLUSIONS}

Comparison and analysis of the above makes it possible to trace an intricate and complex vicious circle (Figure 2), within one block of which, in turn, there are

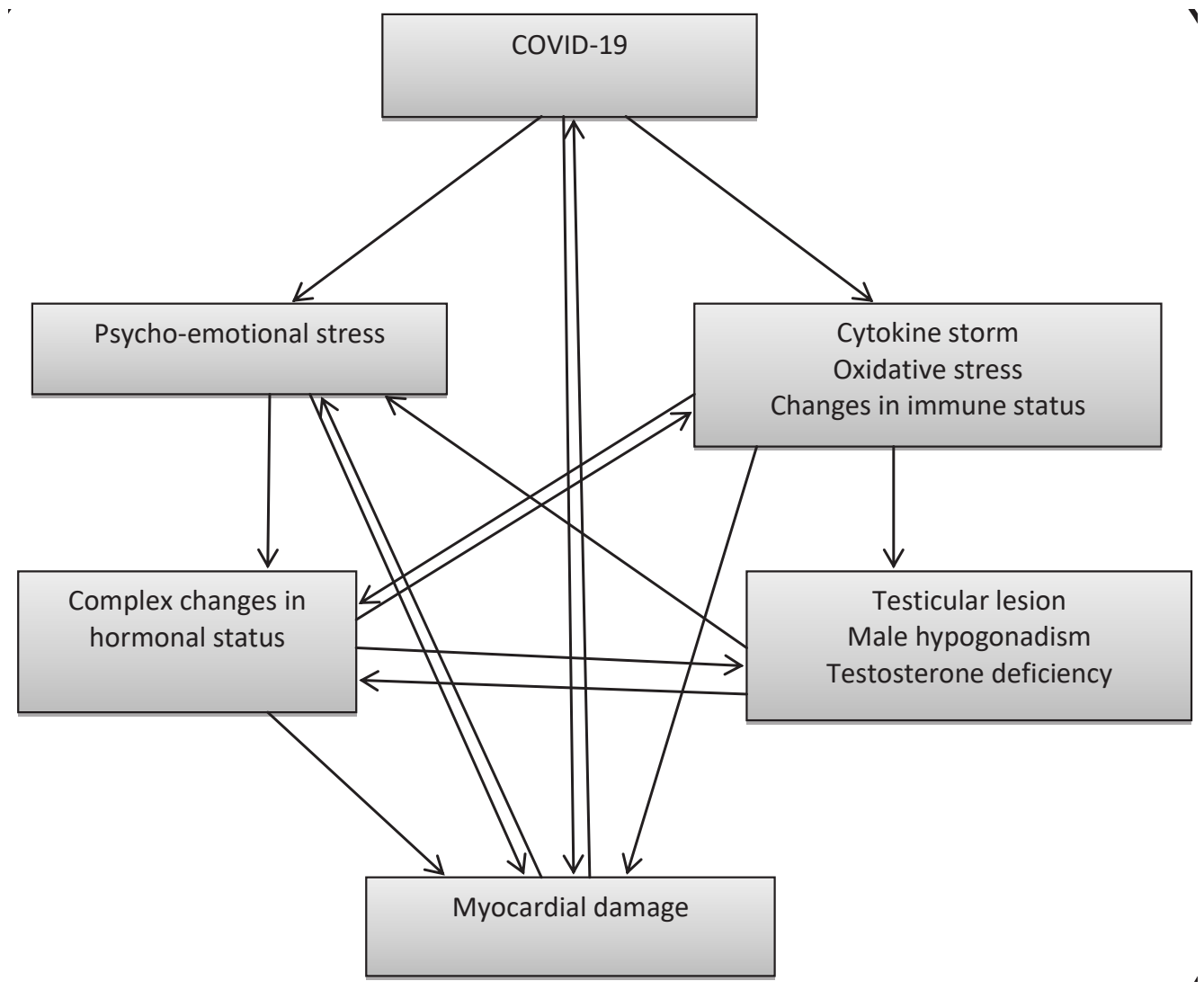


their own inner vicious circles. Scientists around the world are working to be able to influence the weaker parts of the vicious circles at different levels. Given the above, one of the key points is to find a compro- mise, the best option between the need for social isolation through a pandemic and closer communication between people for mutual support (removal of stress from isolation).

\section{REFERENCES}

1. Yang M, Chen S, Huang B, Zhong JM, Su H, Chen YJ, Cao Q, et al. Pathological findings in the testes of COVID-19 patients: Clinical implications. Eur Urol Focus. 2020;15;6(5): 1124-29. DOI: 10.1016/j.euf.2020.05.009. Epub 2020 May 31. PMID: 32563676; PMCID: PMC7261470.

2. Kharbach Y, Khallouk A. Male genital damage in COVID-19 patients: Are available data relevant? Asian Journal of Urology. 21 June 2020. Available from: https://doi. org/10.1016/j.ajur.2020.06.005.

3. Giagulli VA, Guastamacchia E, Magrone T, Jirillo E, Lisco G, De Pergola G, Triggiani V. Worse progression of COVID-19 in men: Is testosterone a key factor? Andrology. 2020;11(10).1111/andr.12836. DOI: 10.1111/ andr.12836. Epub ahead of print. PMID: 32524732; PMCID: PMC7307026.

4. Jóźków P, Mędraś M. Psychological stress and the function of male gonads. Endokrynol Pol. 2012;63(1): 44-9. PMID: 22378097.

5. Fujita K, Terada H, Ling LZ. [Male sexual insufficiency]. Nihon rinsho. Japanese Journal of Clinical Medicine. 1997;55(11): 2908-13. Russian.

6. Burchinsky SG. Circadian rhytms, chronic stress and pharmacoprophylaxy: new possibilities. [Циркадные ритмы, хронический стресс и фрармакопрофилактика: новые возможности]. Semeynaya meditsina. Professionalivent, Kiev, 2015;4(60). 44. Available from: https://www.elibrary.ru/item. asp?id=24932731. Russian.

7. TyuzikovIA, KalinchenkoSYu, VorslovLO, TishovaYuA. Melatonin deficiency as a cause of hormone-metabolic disorders in men. [Десрицит мелатонина как причина гормонально-метаболических нарушений у мужчин] Clinic of professor Kalinchenko (Moscow). Peoples' friendship university of Russia. Russian. Available from: https://www. umedp.ru/upload/iblock/e3f/tuzikov2.pdf. Russian.

8. Kozlov Al, Kozlova MA. Cortisol as a marker of stress. [Кортизол как маркер стресса]. Human Physiology. 2014;40(2): 224-36. Available from: https://www.elibrary.ru/ item. asp?id=21259162. Russian.

9. Goncharov NP, Katsya GV. Neurosteroid dehydroepiandrosterone and brain function. [Нейростероид дегидроэпиандростерон и фуункции мозга]. Human Physiology. 2013;396: 667-74. Available from: https://www. elibrary.ru/item.asp?id=20447175. Russian.

10. Viau V, Meaney MJ. Alpha1 adrenoreceptors mediate the stimulatory effects of oestrogen on stress-related hypothalamic-pituitary-adrenal activity in the female rat. Journal of Neuroendocrinology. 2004;16(1): 72-8. DOI: 10.1111/j.1365-2826.2004.01122.x. Available from: https://europepmc.org/article/MED/14962079.

11. Almeida, S.A., Kempinas, W.G., \& Lamano Carvalho, T.L. Sexual behavior and fertility of male rats submitted to prolonged immobilization-induced stress. Brazilian
Journal of Medical and Biological Research. 2000;33(9): 1105-9. Available from: https://doi.org/10.1590/S0100879X2000000900019.

12. Sankar BR, Maran RR, SivakumarR, GovindarajuluP, Balasubramanian K. Chronic administration of corticosterone impairs LH signal transduction and steroidogenesis in rat Leydig cells. J Steroid Biochem Mol Biol. 2000;72(34): 155-62. DOI: 10.1016/s0960-0760(00)00019-4. PMID: 10775807.

13. López-Calderón A, Ariznavarreta C, GonzálezQuijano MI, Tresguerres JA, Calderón MD. Stress induced changes in testis function. J Steroid Biochem Mol Biol. 1991;40(1-3): 473-9. DOI: 10.1016/0960-0760(91)90217-s. PMID: 1958548.

14. Akinbami MA, Philip GH, Sridaran R, Mahesh VB, Mann DR. Expression of mRNA and proteins for testicular steroidogenic enzymes and brain and pituitary mRNA for glutamate receptors in rats exposed to immobilization stress. The Journal of Steroid Biochemistry and Molecular Biology. 1999;70(4-6): 143-49. DOI: 10.1016/s09600760(99)00102-8.

15. Bedrak E, Chap Z. Activity of LH receptor, LH-stimulated cyclic AMP and testosterone production in the Leydig cell of heat-acclimatized rats. J Endocrinol. 1984;102(2): 167-73. DOI: 10.1677/joe.0.1020167. PMID: 6086801.

16. Daniel J. Selvage, Soon Y. Lee, Loren H. Parsons, Dong O. Seo, Catherine L. Rivier, A Hypothalamic-testicular neural pathway is influenced by brain catecholamines, but not testicular blood flow, endocrinology. 2004;145(4): 17509. Available from: https://doi.org/10.1210/en.2003-1441.

17. Sasagawa I, Yazawa H, Suzuki Y, Nakada T. Stress and testicular germ cell apoptosis. Arch Androl. 2001;47(3): 211-6. DOI: 10.1080/014850101753145924. PMID: 11695845.

18. Takehiko Koji, Yoshitaka Hishikawa, Germ cell apoptosis and its molecular trigger in mouse testes, Archives of Histology and Cytology. 2003;66(1): 1-16. Released June 25, 2004, Online ISSN 1349-1717, Print ISSN 0914-9465. Available from: https://doi.org/10.1679/aohc.66.1, https:// www.jstage.jst.go.jp/article/aohc/66/1/66_1_1/_article/char/en

19. Turner Al, Canny BJ, Hobbs RJ, Bond JD, Clarke $\mathrm{IJ}$, Tilbrook AJ. Influence of sex and gonadal status of sheep on cortisol secretion in response to ACTH and on cortisol and LH secretion in response to stress: importance of different stressors. J Endocrinol. 2002;173(1): 113-22. DOI: 10.1677/joe.0.1730113. PMID: 11927390.

20. Daly W, Seegers CA, Rubin DA, Dobridge JD, Hackney AC. Relationship between stress hormones and testosterone with prolonged endurance exercise. Eur J Appl Physiol. 2005;93(4): 375-80. DOI: 10.1007/s00421-0041223-1. Epub 2004 Nov 20. PMID: 15618989. 
21. Orr T, Mann D. Effects of restraint stress on plasma $\mathrm{LH}$ and testosterone concentrations, Leydig cell LH/hCG receptors, and in vitro testicular steroidogenesis in adult rats. Horm. Behav. 1990;24(3): 324-41. Available from: https:// doi.org/10.1016/0018-506X(90)90013-N, http://www.sciencedirect.com/science/article/pii/0018506X9090013N.

22. Labombarda F, Ghoumari AM, Liere P, et al. Neuroprotection by steroids after neurotrauma in organotypic spinal cord cultures: a key role for progesterone receptors and steroidal modulators of GABA(A) receptors. Neuropharmacology. 2013;71: 46-55. DOI: 10.1016/j.neuropharm.2013.03.010.

23. Kubasov RV. Hormonal changes in response to extreme environment factors. [Гормональные изменения в ответ на экстремальные фракторы внешней среды]. Annals of the Russian Academy of Medical Sciences; 2014. Russian.

Available from: https://vestnikramn.spr-journal.ru/jour/article/view/395, https://doi.org/10.15690/vramn.v69i9-10.1138

24. Ben-Jonathan N. Prolactin (PRL). Encyclopedia of Hormones. Henry HL, Norman AW. (eds.). USA: Academic Press; 2003.

25. Tolis G, Rombopoulos G, Kaltsas D, Katounda E, Kaltzidou V, Angelopoulos N. Prolactin and Stress. Encyclopedia of Stress. Second Edition. G. Fink (ed). USA: Academic Press; 2007.

26. Onaka T, Takayanagi Y, Leng G. Metabolic and stress-related roles of prolactin-releasing peptide. Trends Endocrinol Metab. 2010;21(5): 287-93. DOI: 10.1016/j. tem.2010.01.005. Epub 2010 Feb 1. PMID: 20122847.

27. Badiu C. WILLIAMS TEXTBOOK OF ENDOCRINOLOGY. Acta Endocrinologica (Bucharest). 2019;15(3): 416. Available from: https://doi.org/10.4183/aeb.2019.416.

28. Patochkina NA, Komelkova MV, Tseylikhman OB, Lapshin MS. Stress: psychological, biochemical and psychophysiological aspects: textbook. [Н.A. Паточкина, М.В. Комелькова, О.Б. Цейликман, М.С. Лапшин. Стресс: психологические, биохимические и психофизиологические аспекты: учебное пособие]. Chelyabinsk. Izdatelskiy tsentr YuUrGU; 2017. Russian. Available from: http://www. psihdocs.ru/psihologicheskie-biohimicheskie.html

29. Arthur R, Rohrmann S, Møller H, Selvin E, Dobs AS, Kanarek N, et al. Pre-diabetes and serum sex steroid hormones among US men. European academy of andrology. 2017;5(1): 49-57. Available from: https://onlinelibrary.wiley.com/doi/full/10.1111/andr.12287, https://doi.org/10.1111/ andr.12287.

30. Rastrelli G, Filippi S, Sforza A, Maggi M, Corona G. Metabolic Syndrome in Male Hypogonadism. Front Horm Res. 2018;49:131-155. DOI:10.1159/000485999. Epub 2018 May 24. PMID: 29895018.

31. Obunai K, Jani S, Dangas GD. Cardiovascular morbidity and mortality of the metabolic syndrome. Med Clin North Am. 2007;91(6): 1169-84. DOI: 10.1016/j. mcna.2007.06.003. PMID: 17964915.

32. National Cholesterol Education Program (NCEP) Expert Panel on Detection, Evaluation, and Treatment of High Blood Cholesterol in Adults (Adult Treatment Panel III). Third Report of the National Cholesterol Education Program (NCEP) Expert Panel on Detection, Evaluation, and Treatment of High Blood Cholesterol in Adults (Adult Treatment Panel III) final report. Circulation. 2002;17;106(25): 3143421. PMID: 12485966.
33. Reaven GM. Banting lecture 1988. Role of insulin resistance in human disease. Diabetes. 1988;37(12): 1595-607. PMID: 3056758. Available from: DOI: 10.2337/ diab.37.12.1595.

34. Madhu SV, Aslam M, Aiman AJ, Siddiqui A, Dwivedi S. Prevalence of hypogonadism in male Type 2 diabetes mellitus patients with and without coronary artery disease. Indian J Endocrinol Metab. 2017;21(1): 31-7. DOI: 10.4103/2230-8210.195999.

35. Brand JS, van der Tweel I, Grobbee DE, EmmelotVonk MH, van der Schouw YT. Testosterone, sex hormonebinding globulin and the metabolic syndrome: a systematic review and meta-analysis of observational studies. Int J Epidemiol. 2011;40(1): 189-207. Epub 2010 Sep 24. PMID: 20870782. Available from: doi: 10.1093/ije/dyq158.

36. Zhang J, Huang X, Liao M, Gao Y, Tan A, Yang X, Zhang $\mathrm{H}$, Mo L, Zhang Y, Lu Z, Wu C, Hu Y, Mo Z. Both total testosterone and sex hormone-binding globulin are independent risk factors for metabolic syndrome: results from Fangchenggang Area Male Health and Examination Survey in China. Diabetes Metab Res Rev. 2013;29(5): 391-7. PMID: 23463406. Available from: doi: 10.1002/dmrr.2405. https://onlinelibrary.wiley.com/doi/abs/10.1002/dmrr.2405

37. Fox S, Vashisht R, Siuba M, Dugar S. Evaluation and management of shock in patients with COVID-19. Cleve Clin J Med. 2020;17. DOI: 10.3949/ccjm.87a.ccc052. Epub ahead of print. PMID: 32680896.

38. Permpikul C, Tongyoo S, Viarasilpa T, Trainarongsakul T, Chakorn T, Udompanturak S. Early use of norepinephrine in septic shock resuscitation (CENSER). A Randomized Trial. Am J Respir Crit Care Med. 2019;1;199(9): 1097-105. DOI: 10.1164/rccm.201806-1034OC. PMID: 30704260

39. Ospina-Tascón, G.A., Hernandez, G., Alvarez, I. et al. Effects of very early start of norepinephrine in patients with septic shock: a propensity score-based analysis. Crit Care. 2020;24(52). Available from: https://doi.org/10.1186/ s13054-020-2756-3.

40. Sean van Diepen, Jason N. Katz, Nancy M. Albert, Timothy D. Henry, Alice K. Jacobs, Navin K. Kapur, et al. Contemporary Management of Cardiogenic Shock: A Scientific Statement from the American Heart Assocaition. Circulation. 2017;136: e232-68. Available from: https://doi. org/10.1161/CIR.0000000000000525, https://www.ahajournals.org/doi/10.1161/CIR.0000000000000525.

41. Riddell SR. Adrenaline fuels a cytokine storm during immunotherapy. Nature. 2018;564(7735): 194-6. Available from: DOI: 10.1038/d41586-018-07581-w.

42. Bansal M. Cardiovascular disease and COVID-19. Diabetes Metab Syndr. 2020;14(3): 247-250. Epub 2020 Mar 25. PMID: 32247212; PMCID: PMC7102662. Available from: DOI: 10.1016/j.dsx.2020.03.013.

43. Oudit GY, Kassiri Z, Jiang C, Liu PP, Poutanen SM, Penninger JM, Butany J. SARS-coronavirus modulation of myocardial ACE2 expression and inflammation in patients with SARS. Eur J Clin Invest. 2009;39(7): 618-25. Epub 2009 May 6. PMID: 19453650; PMCID: PMC7163766. Available from: DOI: 10.1111/j.1365-2362.2009.02153.x.

44. Zhou F, Yu T, Du R, Fan G, Liu Y, Liu Z, et al. Clinical course and risk factors for mortality of adult inpatients with COVID-19 in Wuhan, China: a retrospective cohort study. Lancet. 2020;395(10229): 1054-62. Epub 2020 Mar 11. 
45. Giagulli VA, Guastamacchia E, Magrone T, Jirillo E, Lisco G, De Pergola G, Triggiani V. Worse progression of COVID-19 in men: Is testosterone a key factor? Andrology. 2020;11: 10.1111/andr.12836. Epub ahead of print. PMID: 32524732; PMCID: PMC7307026. Available from: DOI: $10.1111 /$ andr.12836.

46. Men with hypogonadism leading to low testosterone levels are more likely to die from the coronavirus, study finds. The Science Times. May 14,2020. Available from: https://www.sciencetimes.com/articles/25685/20200514/ men-hypogonadism-leading-low-testosterone-levels-moredie-coronavirus-study.htm

47. Dutta, S., Sengupta, P. SARS-CoV-2 and Male Infertility: Possible Multifaceted Pathology. Reprod. Sci. 2021;28: 23-6. Available from: https://doi.org/10.1007/ s43032-020-00261-z

48. Dutta S, Majzoub A, Agarwal A. Oxidative stress and sperm function: A systematic review on evaluation and management. Arab J Urol. 2019;24;17(2): 87-97.
PMID: 31285919; PMCID: PMC6600059. Available from: DOI: 10.1080/2090598X.2019.1599624.

49. Sengupta P, Dutta S. Does SARS-CoV-2 infection cause sperm DNA fragmentation? Possible link with oxidative stress. Eur J Contracept Reprod Health Care. 2020;25(5): 405-6. Epub 2020 Jul 9. PMID: 32643968. Available from: doi: 10.1080/13625187.2020.1787376.

50. Delgado-Roche L, Mesta F. Oxidative stress as key player in severe acute respiratory syndrome coronavirus (SARS-CoV) infection. Arch Med Res. 2020;51(5): 384-7. Epub 2020 Apr 30. PMID: 32402576; PMCID: PMC7190501. Available from: DOI: 10.1016/j.arcmed.2020.04.019.

51. Li R, Yin T, Fang F, Li Q, Chen J, Wang Y, et al. Potential risks of SARS-Cov-2 infection on reproductive health. Reprod BioMed Online. 2020;41: 89-95. Available from: https://www.scopus.com/record/display.uri?eid=2s2.0-85085342994\&origin=inward\&txGid=e13c9f3971cc2 dc9817af85d939b1e0e, https://covid19.elsevierpure.com/ da/publications/potential-risks-of-sars-cov-2-infection-onreproductive-health. 